\title{
Edukasi Protokol Kesehatan dalam Masa Pandemi Covid-19 pada Anak Sekolah Dasar di Pesisir Pantai Payum Merauke
}

\author{
Fredy ${ }^{1 *}$, Dewi Puji Rahayu², Karlina Wong Lieung ${ }^{3}$, Ratna Purwanty ${ }^{4}$, Lastika \\ Ary Prihandoko 5 \\ 1,2,3,4,5Universitas Musamus, Merauke, Indonesia \\ ${ }^{*}$ Corresponding Author: fredy_pgsd@unmus.ac.id
}

\begin{abstract}
Info Artikel
Diterima : 03/05/2021

Direvisi: $14 / 05 / 2021$

Disetujui: 28/05/2021

Abstract. Intensive socialization of health protocols was carried out by the government through various media, both printed and electronic, and even made visits to certain places using loudspeakers to stop the spread of COVID-19. However, this does not make most people comply with health protocols properly. This is not because they are stubborn or stubborn but because of their lack of understanding. Therefore, socialization is needed, which is a notification to apply health protocols and educational practices in preventing the transmission of COVID-19, including a clean way of life. This community service program aims to provide an understanding of health protocols as a new habit during the COVID-19 pandemic. The target of this activity is elementary school children who live in the coastal area of Payum Merauke. The method of implementing this activity is in the form of material lectures, questions and answers, and simulations. The results of the service show that children have understanding and skills in practicing health protocols such as how to use masks, maintain distance and wash hands properly and effectively. The percentage of children who can practice health protocols correctly is $89.28 \%$. Likewise, the average percentage of the implementation of each activity reaches $92 \%$. Understanding the health protocol can be hoped to become a new habit so that it can help them avoid transmission and the new cluster of covid-19.
\end{abstract}

Keywords: education, covid-19, health protocol, elementary school

\begin{abstract}
Abstrak. Sosialisasi protokol kesehatan secara intensif dilakukan oleh pemerintah melalui berbagai media baik cetak maupun elektronik bahkan melakukan kunjungan ke tempat-tempat tertentu dengan alat pengeras suara untuk memutus penyebaran covid-19. Namun hal ini tidak membuat sebagian besar masyarakat mematuhi protokol kesehatan dengan baik. Ini bukan karena mereka bandel atau keras kepala namun disebabkan oleh kurangnya pemahaman mereka. Oleh karena itu, diperlukan sosialisasi yang tidak sekedar pemberitahuan menerapkan protokol kesehatan, tetapi melakukan juga praktik edukasi dalam pencegahan penularan covid-19, termaksud di dalamnya cara hidup bersih. Program pengabdian masyarakat ini bertujuan memberikan pemahaman mengenai protokol kesehatan sebagai kebiasaan baru di masa pandemi covid-19. Sasaran kegiatan ini adalah anak sekolah dasar yang tinggal di wilayah pesisir pantai Payum Merauke. Metode pelaksanaan kegiatan ini berupa ceramah materi, tanya jawab dan simulasi. Hasil pengabdian menunjukkan anak memiliki pemahaman dan keterampilan dalam mempraktikkan protokol kesehatan seperti cara menggunakan masker, menjaga jarak dan mencuci tangan dengan benar dan efektif. Persentasi anak yang mampu mempraktikkan protokol kesehatan dengan benar sebesar 89,28\%. Begitu pula dengan persentasi rata-rata keterlaksanaan setiap kegiatan mencapai $92 \%$. Memahami protokol kesehatan diharapkan dapat menjadi kebiasaan baru sehingga dapat membantu mereka terhindar dari penularan dan adanya klaster baru covid-19.
\end{abstract}

Kata Kunci: edukasi, covid-19, protokol kesehatan, sekolah dasar

How to Cite: Fredy,F., Rahayu, D.P., Lieung, K.W., Purwanty, R., \& Prihandoko, L.A. (2021). Edukasi Protokol Kesehatan dalam Masa Pandemi Covid-19 pada Anak Sekolah Dasar di Pesisir Pantai Payum Merauke. Prima Abdika : Jurnal Pengabdian Masyarakat, 1(2), 73-80.

https://doi.org/10.37478/abdika.v1i2.1078

Copyright (c) 2021 Fredy, Dewi Puji Rahayu, Karlina Wong Lieung, Ratna Purwanty, Lastika Ary Prihandoko. This work is licensed under a Creative Commons Attribution-ShareAlike 4.0 International License.

\section{Pendahuluan}

Covid-19 merupakan virus yang sedang menyerang seluruh belahan dunia. Penyebaran virus ini sangat cepat (Mona, 2020). Semula berasal dari kota Wuhan Cina, Covid-19 kini menjangkiti hampir seluruh belahan dunia, termasuk Indonesia (Gazali, dkk, 2020). Gejala yang muncul pada penderita covid-19 berbeda-beda mulai dari yang bersifat ringan hingga berat (Krigja 
dan Muthuri, 2020). Jumlah penduduk yang terinfeksi covid-19 terus bertambah setiap harinya (Yuliana, 2020).

Indonesia sebagai negara kepulauan tentunya memiliki karakteristik yang berbeda-beda untuk setiap daerahnya. Hal tersebut mengharuskan pemerintah harus ekstra bekerja keras dan cepat untuk menangani virus Covid-19 di Indonesia baik berupa pembatasan kegiatan maupun pencegahan penyebaran covid-19 (Utomo, 2020; Susilowati, dkk, 2020). Beragam solusi dilakukan oleh pemerintah untuk mengatasi virus tersebut. Solusi yang dilakukan diantaranya dengan menerapkan social distancing, pembatasan sosial berskala besar (PSBB), protokol kesehatan, work form home, belajar dari rumah dan beragaman solusi lainnya. Beragam solusi tersebut dilakukan oleh pemerintah dengan tujuan agar virus Covid-19 tidak menyebar terlalu banyak di Indonesia.

Sosialisasi protokol kesehatan secara intensif dilakukan oleh pemerintah baik secara langsung maupun perantara berbagai media elektronik maupun cetak. Hal ini bertujuan agar informasi tersebut dapat tersampaikan sampai pelosok negeri tidak terkecuali Kabupaten Merauke. Anak usia sekolah dasar di pesisir pantai perlu mengetahui tentang protokol kesehatan sehingga mereka mampu menjaga dirinya sendiri dan orang di sekitar mereka dalam menghadapi virus Covid-19 menuju era new normal.

Pemberlakuan kebijakan era new normal ditempuh pemerintah dalam upaya menyikapi wabah Covid-19 (Muhyiddin, 2020). Kebijakan new normal tersebut bertujuan untuk kebaikan seluruh rakyat Indonesia (Habibi, 2020; Budianta, 2020). Selain itu kebiajakn ini ditempuh dalam rangka mendorong perekonomian di Indonesia (Alkatiri, Nadiah dan Nasution, 2020). Pelaksanaan era new normal mengharuskan masyarakat melaksanakan kebiasaan baru yang ketat guna menekan angka penularan Covid-19 (Rizal, 2020).

Protokol kesehatan meliputi perlindungan kesehatan diri dan kesehatan masyarakat (Menkes, 2020). Seorang individu dapat mencegah penularan covid-19 dengan menghindari masuknya virus covid-19 melalui mulut, hidung dan mata. Permasalahan yang ada di lapangan adalah anak sekolah di pesisir pantai Payum Merauke memerlukan pengetahuan tentang protokol kesehatan guna menjaga diri dari virus Covid-19. Pengetahuan tentang protokol kesehatan tersebut diperlukan sebagai wawasan mereka dalam menyambut era new normal.

Berdasarkan analisis situasi yang terjadi di lapangan, anak-anak usia sekolah dasar di pesisir Payum Merauke masih bermain dan berkegiatan dengan biasa tanpa mematuhi protokol kesehatan. Anak-anak belum menjaga jarak dengan temannya, belum mencuci tangan setelah berinteraksi dengan temannya dan belum mengenakan masker dengan baik. Yang dimaksud disini yakni, anak-anak menggunakan masker akan tetapi masih sering dibuka dan ditutup. Ketidakpatuhan ini karena kurangnya pengetahuan mereka. Oleh karena itu, sangat diperlukan sosialisasi yang tidak sekedar pemberitahuan menerapkan protokol kesehatan, tetapi melakukan praktik edukasi kepada anak-anak dalam pencegahan penularan covid-19, termaksud di dalamnya cara hidup bersih dan etika batuk dan bersin. Edukasi disini diartikan sebagai integrasi unsur pendidikan dalam pelaksanaan program dan pemberian pemahaman kepada anak sekolah dasar (Yumame et al., 2020). 
Program pengabdian masyarakat ini bertujuan memberikan pemahaman dan keterampilan mengenai protokol kesehatan sehingga dapat menjadi kebiasaan dalam penerapannya di kehidupan sehari-hari. Selain itu juga sebagai upaya membekali mereka pengetahuan dan keterampilan protokol kesehatan sebelum pelaksanaan tatap muka terbatas di tahun ajaran baru.

\section{Metode Pelaksanaan}

Metode kegiatan yang dilakukan adalah berupa edukasi protokol kesehatan Covid-19. Melalui penggunaan metode tersebut diharapkan mempermudah anak sekolah dasar di pesisir Pantai Payum Merauke dalam mengaplikasikan protokol kesehatan menjadi kebiasaan baru dalam kehidupan sehari-hari. Langkah-langkah kegiatan pengabdian ini adalah prakegiatan, pelaksanaan kegiatan dan evaluasi kegiatan. Secara rinci langkah-langkah kegiatan adalah sebagai berikut:

a. Prakegiatan diawali dengan perizinan kepada Lurah Samkai sebagai pemerintah setempat terkait pelaksanaan program pengabdian masyarakat dan sasaran kegiatannya yaitu mengedukasi anak sekolah dasar yang bermukim di sepanjang pesisir pantai Payum Kelurahan Samkai, Kabupaten Merauke, Papua untuk mengadopsi kebiasaan baru protokol kesehatan dalam aktivitasnya sehari-hari. Pemberitahuan juga disampaikan kepada kepala kampung Payum dan orang tua/wali anak mengenai metode pelaksanaan kegiatan sehingga mereka dapat memberitahukan anak-anak mereka untuk mengikuti kegiatan tersebut pada waktu yang telah ditentukan. Selain perizinan, pada tahap ini juga tim pengabdian masyarakat menyiapkan alat dan bahan yang diperlukan seperti tempat cuci tangan, air, sabun cair dan masker.

b. Pelaksanaan kegiatan berupa edukasi protokol kesehatan di masa Pandemi Covid-19 pada anak sekolah dasar. Kegiatan ini dilaksanakan melalui beberapa metode, yaitu: (1) pemaparan informasi pentingnya mematuhi protokol kesehatan di masa pandemi melalui metode ceramah. Hal ini dimaksudkan untuk memberikan penjelasan tentang urgensi mematuhi protokol kesehatan di masa pandemi ini, (2) melakukan tanya jawab. Metode tanya jawab memungkinkan untuk sharing informasi dan pengetahuan anak tentang Covid-19 dan langkah-langkah pencegahannya, (3) melakukan simulasi. Bertujuan sebagai sarana anak untuk mempraktikkan protokol kesehatan dengan benar dan efektif seperti cara pakai masker, menjaga jarak fisik, dan mencuci tangan. Harapannya anak mampu menerapkan protokol kesehatan dan menjadi kebiasaan baru dalam kehidupan sehari-hari mereka. Keberhasilan pelaksanaan kegiatan ini adalah persentasi anak yang terampil dalam mempraktikkan protokol kesehatan dengan benar di atas $80 \%$ dari jumlah anak yang mengikuti kegiatan pengabdian ini.

c. Evaluasi program dimaksudkan untuk mengetahui sejuah mana tingkat keberhasilan program pengabdian. Evaluasi dilakukan dengan menghitung persentasi tingakat keterlaksanaan setiap tahapan kegiatan. Keterlaksanaan pada setiap kegiatan harus memenuhi persentasi minimal $90 \%$. 


\section{Hasil dan Pembahasan}

Pelaksanaan program mengikuti tahapan yang telah direncanakan. Diawali dengan perizinan kepada Lurah Samkai, Kepala Kampung Payum dan Orangtua/Wali anak. Pada dasarnya mereka mendukung kegiatan tersebut sebagai usaha menekan dan memutus rantai penularan covid-19. Sejauh ini Pemerintah telah melakukan himbauan melalui media cetak, elektronik dan melalui alat pengeras suara mobil patroli atau diskominfo, namun belum berdampak optimal pada kepatuhan sebagian besar masyarakat khususnya di wilayah pesisir pantai. Masih banyaknya aktivitas masyarakat di luar rumah tanpa menggunakan masker, berkumpul-kumpul tanpa adanya jarak, dan anak-anak bermain berkelompok. Ketidakpatuhan sebagian besar masyarakat ini bukan sikap bandel atau "keras kepala" tetapi disebabkan oleh rendahnya pemahaman mereka mengenai protokol kesehatan. Untuk itu sosialisasi yang dibutuhkan tidak hanya himbauan tetapi juga edukasi perilaku hidup bersih dan praktik protokol kesehatan secara intens terkait pencegahan dan penularan Covid-19 (Ilham et al., 2021).

1. Penyampaian materi pentingnya mematuhi protokol kesehatan.

Pelaksanaan kegiatan ini menggunakan metode ceramah. Hal ini bertujuan untuk memberikan pemahaman kepada anak tentang bahaya Covid-19 dan pentingnya menerapkan protokol kesehatan di masa pandemi ini. Pemateri menyampaikan bahwa protokol kesehatan harus menjadi kebiasaan baru dalam menjalankan aktivitas kita sehari-hari. Dengan begitu kita turut serta membantu pemutusan penyebaran covid-19 dan mencegah munculnya klaster baru. Ingat "pesan ibu" selalu terapkan 3M yaitu menjaga jarak, memakai masker, dan mencuci tangan.

a. Menggunakan masker dengan benar saat beraktivitas di luar rumah dan berinteraksi dengan orang lain. Penggunaan masker dengan benar dilakukan dengan cara:

1) Mencuci tangan dengan sabun atau hand sanitizer sebelum memakai masker

2) perhatikan kondisi masker. Pastikan masker dalam keadaan bersih dan tidak rusak

3) kaitkan tali masker kebelakang telinga sampai dengan menutup hidung, mulut dan dagu dengan sempurna

4) jangan menyentuh depan masker agar tangan tetap bersih

5) Jika melepas masker, dimulai dari melepas tali belakang. Jangan diturunkan di area dagu.

6) Kembali mencuci tangan dengan sabun atau hand sanitizer setelah melepas masker. Jika menggunakan masker kain, cucilah setiap hari dengan deterjen. 


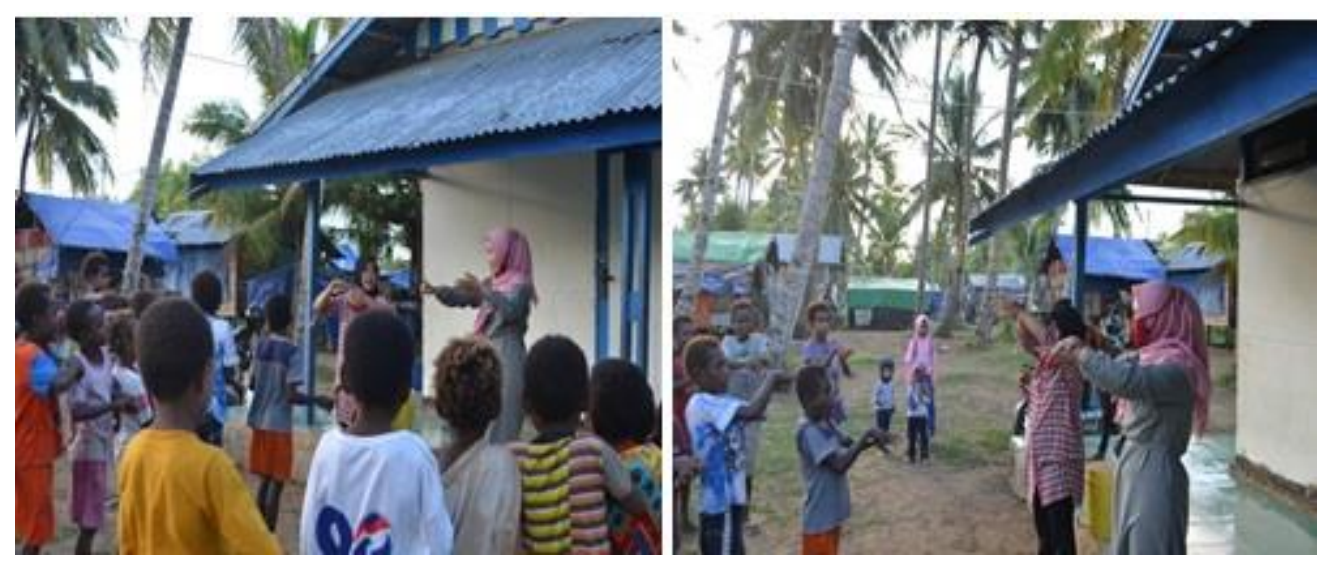

Gambar 1. Pemaparan materi

b. Jaga jarak dengan teman dan hindari keramaian. Dengan jaga jarak kita dapat mencegah dari paparan Covid-19. Selain itu dengan tidak berkumpul-kumpul menghindari kemungkinan tertular, karena banyak orang yang menunjukkan tanpa gejala tetapi telah terpapar covid-19. Dalam kegiatan ini pula diajarkan etika dalam bersin dan batuk di tempat umum. Kendala yang ditemui dalam penyampaian materi adalah anak-anak yang semula dapat mengikuti materi dengan menjaga jarak namun beberapa saat kemudian jarak mereka kembali rapat sehingga tim pengabdian harus mengatur kembali agar mereka dapat menjaga jarak aman.

c. Mencuci tangan sebelum menyentuh area muka seperti mulut, mata dan hidung. Dengan mencuci tangan pakai sabun atau hand sanitizer dapat membunuh kuman penyakit sehingga penting dilaksanakan dengan rutin. Cara mencuci tangan yang benar menurut WHO terdiri atas enam langkah, yaitu: ambil sabun dan menggosokan pada kedua telapak tangan, menggosok punggung tangan dan menyela jari kedua tangan, menggosok telapak dan sela jari kedua tangan, gosok punggung jari kedua tangan dengan posisi tangan saling mengunci, menggosok ibu jari dengan memutar secara bergantian, usapkan ujung jari dengan diputar pada telapak tangan secara bergantian dan basuh dengan air mengalir (WHO, 2020). Membiasakan mencuci tangan dengan benar dapat dilakukan melalui pembelajaran guru di sekolah atau dengan bimbingan orang tua di rumah (Suprapto et al., 2020).

2. Melakukan tanya jawab

Pemateri bertanya jawab dengan anak untuk sharing informasi dan pemahaman mereka tentang covid-19 dan langkah-langkah pencegahannya. Hasil tanya jawab yang dilakukan menunjukkan bahwa memang masih banyak anak-anak yang belum paham penerapan protokol kesehatan dengan benar dan efektif.

3. Melakukan simulasi

Tim pengabdian masyarakat melakukan simulasi mencuci tangan dan memakai masker dengan benar dan efektif. Anak-anak dipandu dalam mempraktikkan cara mencuci tangan, menggunakan masker dan menjaga jarak. Melalui simulasi ini anak memiliki pengetahuan dan terampil 
melaksanakan protokol kesehatan dengan benar dan efektif sehingga dapat menjaga diri mereka di masa pandemi.
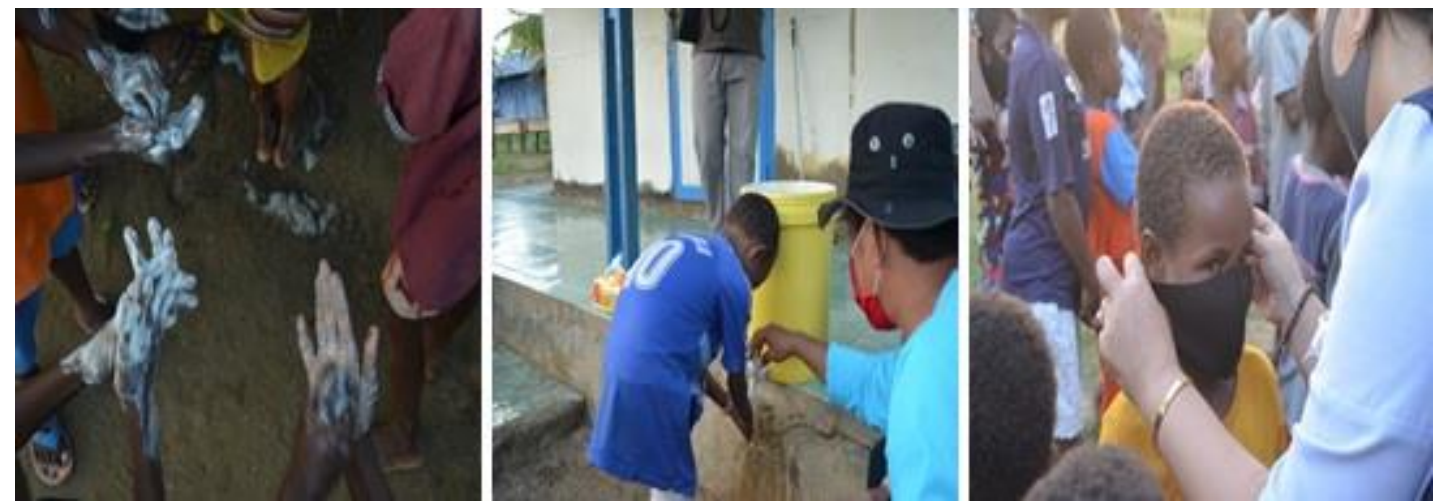

Gambar 2. Praktik mencuci tangan dan memakai masker

Persentasi anak yang mampu dan terampil mencuci tangan dan memakai masker dengan benar sebesar $89,28 \%$. Begitu pula dengan persentasi ratarata keterlaksanaan setiap kegiatan mencapai 92\%. Ini telah memenuhi standar yang ditetapkan. Langkah terakhir pelaksanan kegiatan ini adalah dengan melakukan pembagian masker kepada anak-anak, orangtua/wali dan masyarakat di wilayah pesisir pantai Payum dengan harapan masyarakat semakin sadar dan patuh dalam menerapkan protokol kesehatan sebagai kebiasaan baru di masa pandemi. Patuh dan taat pada anjuran pemerintah merupakan wujud dukungan dan partisipasi masyarakat dalam menekan dan memutus penularan Covid-19 dan mencegah munculnya klaster atau varian baru covid-19 (Ilham et al., 2021).

\section{Simpulan dan Tindak Lanjut}

Program pengabdian masyarakat ini berupa edukasi protokol kesehatan pada masa pandemi covid-19 pada anak sekolah dasar di pantai Payum Merauke penting dilaksanakan sebagai wujud dan tanggung jawab tim pengabdian dalam mendukung usaha bersama memutus rantai penyebaran Covid-19. Kegiatan ini berjalan sesuai rencana dan mendapat dukungan penuh dari pemerintah kelurahan, kepala kampung dan orangtua/wali anak. Melalui program ini, anak memiliki pemahaman dan kepatuhan dalam menerapkan kebiasaan baru dalam segala aktivitasnya baik di lingkungan keluarga, masyarakat maupun sekolah. Dengan memahami cara memakai masker yang benar dalam beraktivitas di luar rumah, menjaga jarak aman, mencuci tangan sebelum dan setelah beraktivitas, menghindari kerumunan dapat membantu mereka terhindar dari penularan dan adanya klaster baru covid-19. Edukasi perilaku hidup bersih dan praktik protokol kesehatan sebaiknya dilakukan secara rutin dan intens guna membudayakan kebiasaan baru dan mencegah penyebaran Covid-19 yang lebih luas. 


\section{Daftar Pustaka}

Alkatiri, A. B. M., Nadiah, Z., dan Nasution, A. N. S. (2020). Opini Publik terhadap Penerapan New Normal Di Media Sosia Twitter, Journal of Strategic Communication, 11(1). 19-26. Retrieved from http://journal.univpancasila.ac.id/index.php/coverage/article/view/ 1728

Budianta, A. (2020). Kehidupan Baru, Adaptasi Hadapi Pandemi. Kementerian Keuangan Republik Indonesia. Diakses 28 Juli 2021 pada https://www.djkn.kemenkeu.go.id/artikel/baca/13107/Kehidupan-BaruAdaptai-Hadapi-Pandemi.html

Gazali, M, dkk. (2020). Sosialisasi Protokol Kesehatan SebagaiUpaya Pencegahan Covid-19 Kepada Masyarakat Nelayan Di Pesisir Kuala Bubon Kabupaten Aceh Barat. Jurnal Marine Kreatif. 4 (2). 56-62. http://jurnal.utu.ac.id/mkreatif/article/view/3009/1840

Habibi, A. (2020). Normal Baru Pasca Covid-19. Jurnal ADALAH: Buletin Hukum \& Keadilan 4(1), 197-202. Retrieved from http://journal.uinjkt.ac.id/index.php/adalah/article/view/ 15809

Menteri Kesehatan RI. (2020). Keputusan Menteri Kesehatan Republik Indonesia Nomor HK.01.07/MENKES/382/2020 Tentang Protokol Kesehatan Bagi Masyarakat Di Tempat Dan Fasilitas Umum Dalam Rngka Pencegahan Dan Pengendalian Corona Virus Disease 2019 (COVID-19). $\quad$ Diakses 28 Juli 2021 pada http://hukor.kemkes.go.id/uploads/produk_hukum/KMK_No_HK_01_0 7-MENKES-382-

2020_ttg_Protokol_Kesehatan_Bagi_Masyarakat_di_Tempat_dan_Fasilitas_ Umum_Dalam_Rangka_Pencegahan_COVID-19.pdf

Krigia, J. M., dan Muthuti, R. N. D. K. (2020). The Fiscal Value of Human Lives Lost From Coronavirus Disease (COVID-19) in China. BMC Research Notes 13 (1), 1-5. https://doi.org/10.1186/s13104-020-05044-y

Ilham, Renyaan, D., Sapioper, H. C. M., \& Yumame, J. (2021). Edukasi Membudayakan Protokol Kesehatan Pada Masa Pandemi Covid-19 Di Kampung Yobeh Distrik Sentani Kabupaten Jayapura. JMM (Jurnal Masyarakat Mandiri), 5(Vol 5, No 1 (2021): Februari), 12-23. http://journal.ummat.ac.id/index.php/jmm/article/view/3186/pdf

Mona, N, (2020). Konsep Isolasi Dalam Jaringan Sosial Untuk Meminimalisasi Efek Contagious (Kasus Penyebaran Virus Corona Di Indonesia). Jurnal Sosial Humaniora Terapan. 2(2), 117-125. https: / / doi.org/10.7454/.jsht.v2i2.86

Muhyiddin. (2020). Covid-19, New Normal, dan Perencanaan Pembangunan di Indonesia, Jurnal Perencanaan Pembangunan: The Indonesia Journal of Development Planning, 4(2), 240-252. https://doi.org/ 10.36574/.jpp.v4i2.118

Rizal, J. G. (2020). Tentang New Normal Life, Hidup Berdamai dengan Covid19 seperti Diungkapkan Presiden Jokowi. Diakses 28 Juli 2021 pada https: / /www.kompas.com/tren/read/2020/05/09/201453065/tentangnew-normal-life-hidup-berdamai-dengan-covid-19-sepertidiungkapkan?page $=$ all

Suprapto, R., Hayati, M., Nurbaity, S., Anggraeni, F., Haritsatama, S., Sadida, T. Q., Firoh, A., \& Pratama, F. A. (2020). Pembiasaan Cuci Tangan yang Baik dan Benar pada Siswa Taman Kanak-Kanak (TK) di Semarang. 


$\begin{array}{llll}\text { Jurnal Surya } & \text { Masyarakat, } & 2(2), & 139 .\end{array}$

https://doi.org/10.26714/.jsm.2.2.2020.139-145

Susilowati, dkk. (2020). Pengabdian Msyarakat Melalui Sosialsi Protokol Kesehatan Menghadapi Pandemi Covid-19. Jurnal Pembelajaran Pemberdayaan Masyarakat, 300-304 http://riset.unisma.ac.id/index.php/JP2M/article/view/9003

Utomo, A. P. (2020). WHO Umumkan Virus Corona Sebagai Pandemi Global. Kompas.com,Retrieved from https: / /www.kompas.com/global/read/2020/03/12/001124570/whoumumkan-virus-corona-sebagai-pandemi-global?page=all

World Health Organization. (2020). WHO Coronavirus Disease (COVID-19) Dashboard. Retrieved May 17, 2020, from https://covid19.who.int/?gclid=EAI aIQobChMI4taCysi76QIVDyQrCh0 jIgdKEAAYASAAEgJUR_D_BwE,

Yuliana. (2020). Corona virus disease (Covid-19): Sebuah Tinjauan Literatur. Wellness and Healthy Magazine, 2(1), 187-192. https: / / doi.org/10.2307/j.ctvzxxb18.12

Yumame, J., Ilham, Renyaan, D., \& Sapioper, H. (2020). Membangun Kampung Berbasis Data (Pendampingan Penyusunan Monografi dan Profil Kampung Yobeh Distrik Sentani Kabupaten Jayapura). Communnity Development Journal, 1(3), 246-253. 